\title{
Pathobiochemical Mechanisms Relating Iron Homeostasis to Parameters of Inflammatory Activity and Autoimmune Disorders in Rheumatoid Arthritis
}

\author{
Katya I. Stefanova ${ }^{1}$, Ginka T. Delcheva ${ }^{1}$, Ana I. Maneva ${ }^{1}$, Anastas Z. Batalov' ${ }^{2}$, Mariela G. \\ Geneva-Popova ${ }^{2}$, Rositza V. Karalilova ${ }^{2}$, Kiril K. Simitchiev ${ }^{3}$ \\ ${ }^{1}$ Department of Chemistry and Biochemistry, Faculty of Pharmacy, Medical University of Plovdiv, Plovdiv, Bulgaria \\ ${ }^{2}$ Department of Propaedeutics of Internal Diseases, Faculty of Medicine, Medical University of Plovdiv, Plovdiv, Bulgaria \\ ${ }^{3}$ Department of Analytical Chemistry and Computer Chemistry, Faculty of Chemistry, Paisii Hilendarski University of Plovdiv, \\ Plovdiv, Bulgaria
}

\section{Correspondence:}

Katya I. Stefanova, Department of Chemistry and Biochemistry, Faculty of Pharmacy, Medical University of Plovdiv, 15A Vassil Aprilov Blvd., 4002 Plovdiv, Bulgaria

E-mail:katia_i_k@yahoo.com Tel: +35932602358

Received: 06 Oct 2015

Accepted: 07 Oct 2016

Published Online: 12 Oct 2016

Published: 23 Dec 2016

Key words: anemia, rheumatoid arthritis, sTfR, ferritin, prohepcidin, IL-6

Citation: Stefanova KI, Delcheva GT, Maneva Al, Batalov AZ, Geneva-Popova MG, Karalilova RV, Simitchiev KK. Pathobiochemical mechanisms relating iron homeostasis to parameters of inflammatory activity and autoimmune disorders in rheumatoid arthritis.

Folia Medica 2016;58(4):257-263 doi: 10.1515/folmed-2016-0040
Aim: To find the correlations between the parameters of iron homeostasis, inflammatory activity and autoimmune disorders in rheumatoid arthritis (RA).

Materials and methods: The present study included 114 patients with RA and 42 healthy controls. We determined the parameters of iron homeostasis: serum iron, total iron binding capacity (TIBC), ferritin and soluble transferrin receptor (sTfR), the parameters of inflammatory activity: C-reactive protein (CRP), interleukin-6 (IL-6) and prohepcidin, and the parameters of autoimmune disorders: rheumatoid factor (RF), anti-cyclic citrullinated peptide (antiCCP) antibodies, and DAS 28.

Results: The levels of STfR, CRP, IL- 6 and prohepcidin were significantly higher in RA patients than those in the controls and the level of serum iron was significantly lower in RA than that in the control group. Unlike the controls, in RA, there was a significant positive correlation of sTfR with the parameters of inflammatory activity (IL-6, prohepcidin, ESR) and with the parameters of autoimmune disorders (DAS $28, \mathrm{RF}$, antiCCP). A negative correlation of serum iron with sTfR was found only in RA patients. Prohepcidin positively correlated with the parameters of inflammation (CRP, ESR) and with the parameters for evaluation of autoimmune disorders (DAS 28 and RF) in the RA group.

Conclusion: Our study shows that the simultaneous determination of the two parameters STfR and prohepcidin is most informative in evaluating the changes in iron homeostasis in RA. The increase of both parameters provides information for tissue iron deficiency (assessed by the level of sTfR), caused by the inflammation when prohepcidin is expressed.

\section{BACKGROUND}

Hypoferremia is a common response to systemic infections or inflammation characterized by iron sequestration in its stores as a protective mechanism and manifestation of anemia. ${ }^{1,2}$ The proinflammatory cytokine interleukin-6 (IL-6) plays a key role in anemia of chronic disease (ACD), also called anemia of inflammation, through induction of the iron-regulatory hormone hepcidin which is responsible for most of the disorders in anemia of chronic inflammatory processes. ${ }^{3}$ Hepcidin is a peptide hormone secreted by the liver in response to inflam- matory stimuli and iron overload. It is synthesized as a preproform - preprohepcidin composed of 84 amino acids. ${ }^{4,5}$

Rheumatoid arthritis (RA) is a systemic autoimmune disease that involves a chronic, progressive inflammation. The changes in iron homeostasis in RA may be due to ACD, iron deficiency anemia (IDA) or both. ${ }^{6-9}$ As anemia in RA may cause severe symptoms and aggravation of other diseases manifestations, early detection of anemia is of vital importance. ${ }^{9}$

Transferrin receptor is a membrane glycoprotein 
composed of two monomers bound together by two disulfide bonds. The content of the soluble form of the receptor sTfR in plasma is proportional to the amount of transferrin on the surface of hematopoietic cells ${ }^{10}$ and reflects the extent of iron deficiency. The advantage of measuring sTfR is that there are only two conditions related to high sTfR: 1) increased production of erythrocytes and; 2) tissue iron deficiency. ${ }^{11}$

There is no clear evidence in literature concerning the diagnostic value of $\operatorname{sTfR}^{12,13}$ and serum ferritin. ${ }^{14}$ Also, the comments on the associations of iron homeostasis parameters with markers of inflammatory activity and autoimmune disorders in RA differ from one another. ${ }^{15-18}$ This can possibly be accounted for by differences in the number of patients, their involvement in common groups with rheumatology diseases or the usage of different methods for evaluation.

\section{AIM}

The aim of the study was to find the correlations between the parameters of iron homeostasis, inflammatory activity and autoimmune disorders in rheumatoid arthritis (RA).

\section{MATERIALS AND METHODS}

Patients: The present study included 114 patients with RA (16 males and 98 females, mean age 58 $\pm 10 \mathrm{yrs}$ ) and 42 healthy controls. We determined the parameters of disease activity and autoimmune disorders - disease activity score 28 (DAS 28): 5.7 $\pm 1.2, \mathrm{n}=114$; RF: 56 (20-198), $\mathrm{n}=107$; antiCCP antibodies: 140 (54-246), $\mathrm{n}=67$.

The study was approved by the Ethics Committee of the Medical University of Plovdiv. All participants gave informed consent before being recruited for the study.

Laboratory analysis: The following parameters were determined: for iron homeostasis - serum iron, total iron binding capacity (TIBC), ferritin, and sTfR; for inflammatory activity - C-reactive protein (CRP), IL-6, and prohepcidin; for autoimmune disorders - RF, antiCCP, and DAS 28.

Laboratory tests such as erythrocyte count, hemoglobin $(\mathrm{Hb})$, erythrocyte sedimentation rate (ESR), TIBC were performed using standard laboratory methods.

Serum ferritin, sTfR, CRP, IL-6 were determined using commercially available kits (BioVendor - Laboratornimedicina, Czech Republic) by ELISA. The concentration of serum prohepcidin was measured by
ELISA using a commercial kit (DRG Instruments, $\mathrm{GmbH}$, Germany), according to the manufacturer's instructions. RF was determined with ELISA kits (Nova Tec Immundiagnostica, GmbH, Germany) and antiCCP with ELISA kits (Eurodiagnostica, Sweden).

\section{Statistics}

Statistical analysis was performed using SPSS version 17.0 (SPSS Inc., Chicago, IL, USA). The concentrations of the parameters of iron homeostasis, inflammation and autoimmune disorders were tested for normality with Kolmogorov-Smirnov test. Data were given as mean $\pm \mathrm{SD}$ or as median and 25thpercentile and 75th-percentile. T-test was used to compare two groups with normal distribution and Mann-Whitney U test was used to compare groups with non-normal distribution. Correlations between data were evaluated by calculating the Pearson's or Spearman's correlation coefficient depending on the distribution of the continuous variables. $\mathrm{P}<0.05$ was considered as statistically significant.

\section{RESULTS}

No significant difference was found in ferritin level between healthy controls and RA patients although the median in the RA group was higher (Table 1). There was a significant positive correlation between ferritin and serum iron in the control group which was absent in RA group (Table 2). There was a negative correlation between TIBC and ferritin in the RA group but not in the control group. The ferritin levels did not correlate with sTfR and IL-6 in the RA and control groups (Table 2).

The sTfR level was significantly higher in the RA group than in the control group $(\mathrm{P}<0.001)$ (Table 1). Unlike the control group, there was a significant positive correlation of STfR with the parameters of inflammatory activity - IL- 6 and prohepcidin in the RA group (Table 2). We found positive correlation of sTfR with CRP in RA and control group, while negative correlation of serum iron with CRP was found only in the RA group (Table 2). sTfR positively correlated with ESR in RA (Table 4). There was a significant negative correlation of TIBC with CRP only in RA group (Table 2). We found associations in the changes of sTfR with parameters of disorders, specific for the autoimmune response in RA: significant positive correlation with DAS 28, $\mathrm{RF}$ and antiCCP antibodies (Table 4).

Serum iron was significantly higher in the control group than the RA group ( $\mathrm{P}=0.014)$ (Table 1). There was a negative correlation of serum iron with IL-6 both in healthy controls and RA patients (Table 2). 
In RA, serum iron negatively correlated with ESR and DAS 28 (Table 4).

There was no significant difference in TIBC between healthy controls and RA (Table 1) and correlations of TIBC with sTfR in the control and RA groups were not found (Table 2). TIBC had significant negative correlations with the parameters of specific disorders in RA - DAS 28 and antiCCP antibodies (Table 4).

The level of $\mathrm{Hb}$ and erythrocyte count were determined in RA patients. The mean of $\mathrm{Hb}$ was $126.45 \pm 13.05, \mathrm{n}=114$ and the median of RBC: 4.44 (4.16-4.72), $\mathrm{n}=106$. We found the following positive correlations: serum iron and $\mathrm{Hb}(\mathrm{n}=57, \mathrm{r}=0.457$, $\mathrm{P}<0.001)$; serum iron and $\mathrm{RBC}(\mathrm{n}=53, \mathrm{r}=0.450$, $\mathrm{P}=0.001) ; \mathrm{Hb}$ and $\mathrm{RBC}(\mathrm{n}=106, \mathrm{r}=0.628, \mathrm{P}<0.001)$. $\mathrm{Hb}$ and $\mathrm{RBC}$ negatively correlated with fibrinogen (Table 4). The level of $\mathrm{Hb}$ negatively correlated with ESR, CRP and IL-6 (Table 4).

The level of prohepcidin was increased in RA compared to healthy controls $(\mathrm{P}=0.013)$ (Table 1). In RA, there were significant positive correlations of prohepcidin with CRP (Table 2) and with ESR, DAS 28 and RF (Table 3).

IL-6 concentration was significantly higher in RA than controls, $\mathrm{P}=0.002$ (Table 1). Positive correlations of IL- 6 with ESR, CRP and DAS 28 were found in RA patients (Table 3).

\section{DISCUSSION}

ACD may be diagnosed by determination of serum parameters of iron homeostasis - serum iron, TIBC (saturation of transferrin with iron), transferrin concentration, ferritin and sTfR. ${ }^{17}$ In RA the form of anemia may be ACD, IDA or both (ACD + IDA). Since anemia in RA may cause severe complications, researchers are making efforts to find appropriate methods for early detection, monitoring and treatment of the condition. Unlike "pure iron deficiency", in anemia of chronic inflammation, the target for therapy is the major disease process. ${ }^{19,20}$

The sTfR level in serum is considered a key marker in ACD research. ${ }^{21}$ The studies show also that STfR is a reliable laboratory index of IDA and in distinguishing IDA from ACD. ${ }^{13}$ According to some authors, anemia of chronic inflammation proceeds with decreased level of STfR and that distinguishes it from the anemia caused by insufficient dietary intake of iron. ${ }^{19}$ Other authors report that increased level of sTfR is a feature of functional iron deficiency, despite the adequate iron stores as it is in chronic inflammatory processes. ${ }^{22}$ Our results confirm the latter finding (Table 1). The study of the correlations of STfR with the other parameters of iron homeostasis, inflammatory activity and autoimmune disorders show that sTfR provides most evidence as it links the pathogenetic mechanisms of iron metabolism with the autoimmune disorders

Table 1. Comparison between parameters of iron homeostasis and inflammation in patients with RA and healthy controls

\begin{tabular}{lccc}
\hline \multicolumn{1}{c}{ Parameters } & Controls & RA patients & P \\
\hline sTfR, $\mu \mathrm{g} / \mathrm{ml}$ & $0.77(0.58-0.91)$ & $1.04(0.67-1.50)$ & $<0.001$ \\
& $\mathrm{n}=42$ & $\mathrm{n}=114$ & \\
Ferritin, $\mathrm{ng} / \mathrm{ml}$ & $31.4(18.0-59.8)$ & $40.5(22.3-78.7)$ & $\mathrm{NS}$ \\
& $\mathrm{n}=42$ & $\mathrm{n}=114$ & \\
Serum iron, $\mu \mathrm{mol} / \mathrm{l}$ & $18.8 \pm 6.1$ & $14.6 \pm 6.8$ & 0.014 \\
& $\mathrm{n}=21$ & $\mathrm{n}=57$ & $\mathrm{NS}$ \\
TIBC, $\mu \mathrm{mol} / \mathrm{l}$ & $63.7 \pm 8.9$ & $59.3 \pm 10.0$ & \\
& $\mathrm{n}=21$ & $\mathrm{n}=57$ & 0.003 \\
CRP, $\mu \mathrm{g} / \mathrm{ml}$ & $2.0(1.9-2.5)$ & $\mathrm{n}=114$ & \\
& $\mathrm{n}=42$ & $4.00(1.17-11.95)$ & 0.002 \\
IL-6, pg/ml & $1.51(0.76-2.30)$ & $\mathrm{n}=59$ & \\
& $997 \pm 477$ & $1262 \pm 796$ & 0.013 \\
Prohepcidin, $\mathrm{ng} / \mathrm{ml}$ & $\mathrm{n}=42$ & $\mathrm{n}=114$ & \\
& & &
\end{tabular}


Table 2. Correlations between parameters of iron homeostasis and inflammation in RA patients and healthy controls

\begin{tabular}{|c|c|c|c|c|c|c|}
\hline \multirow{2}{*}{ Parameters } & \multicolumn{3}{|c|}{ RA patients } & \multicolumn{3}{|c|}{ Controls } \\
\hline & $\mathbf{n}$ & $\mathbf{r}$ & $\mathbf{P}$ & $\mathbf{n}$ & $\mathbf{r}$ & $\mathbf{P}$ \\
\hline Ferritin / TIBC & 57 & -0.606 & $<0.001$ & 21 & -0.415 & NS \\
\hline Ferritin / Serum iron & 57 & 0.152 & NS & 21 & 0.437 & 0.048 \\
\hline Ferritin / IL-6 & 59 & 0.083 & NS & 21 & -0.213 & NS \\
\hline sTfR / Serum iron & 57 & -0.306 & 0.020 & 21 & -0.110 & NS \\
\hline sTfR / Ferritin & 114 & -0.124 & NS & 42 & -0.001 & NS \\
\hline sTfR / TIBC & 57 & 0.045 & NS & 21 & 0.202 & NS \\
\hline sTfR / Prohepcidin & 114 & 0.338 & $<0.001$ & 42 & 0.070 & NS \\
\hline sTfR / CRP & 114 & 0.451 & $<0.001$ & 42 & 0.441 & 0.003 \\
\hline sTfR / IL-6 & 59 & 0.456 & $<0.001$ & 21 & -0.127 & NS \\
\hline Prohepcidin / CRP & 114 & 0.265 & 0.004 & 42 & 0.253 & NS \\
\hline Serum iron / CRP & 57 & -0.416 & 0.001 & 21 & -0.099 & NS \\
\hline Serum iron / IL-6 & 57 & -0.378 & 0.004 & 21 & -0.460 & 0.036 \\
\hline CRP / IL-6 & 59 & 0.553 & $<0.001$ & 21 & 0.049 & NS \\
\hline TIBC / CRP & 57 & -0.297 & 0.025 & 21 & -0.247 & NS \\
\hline
\end{tabular}

in RA (Tables 1-4). The comparison with healthy controls clearly indicates that only in RA there is a positive correlation of iron requirement (sTfR) with the release of the proinflammatory cytokine IL-6 and the hormone hepcidin (assessed by the prohepcidin content) (Table 2 ). The same associations are observed between STfR and the parameters of evaluation of the disorders in RA - DAS 28, RF and antiCCP (Table 4). The negative correlation of serum iron with sTfR level also confirms the informative value of the parameter - the adaptive pathologic mechanism of iron sequestration in its stores, due to the chronic inflammation in RA, causes cellular iron deficiency and in response the cells increase the expression of transferrin receptors. Such correlation was not observed in the control group (Table 2 ).

The individual acute phase proteins provide less information for evaluation of the disease process in RA. Therefore specific parameters that comprise these proteins in total are accepted. An example of such a parameter is DAS 28. ${ }^{23}$ Probably because ferritin is both an iron binding protein and an acute phase protein ${ }^{14}$, its informative value for evaluation of iron homeostasis in RA is limited. The results we obtained showed no significant association of sTfR and serum iron with serum ferritin in RA, while in healthy controls ferritin positively correlated with serum iron and reflected iron stores (Table 2). Serum ferritin had a negative correlation with TIBC in RA which indicated inability for usage of the stored iron (Table 2). A negative correlation of TIBC with serum ferritin and CRP (Table 2) and with specific rheumatoid disorders DAS 28 and antiCCP was found in RA patients only (Table 4). These results indicated that TIBC reflected the grade of inflammation and autoimmune process but not the grade of iron deficiency, which was in agreement with the findings of other authors. ${ }^{24}$

Some authors reject the informative value of serum iron determination as a parameter of anemia in RA. ${ }^{18}$ Our results indicate that serum iron reflects the iron deficiency and inflammatory activity: the amount of serum iron was significantly higher in healthy controls compared to RA $(\mathrm{P}=0.014)$ (Table 1), which confirmed the hypoferremia condition in RA patients. Serum iron negatively correlated with IL-6 in healthy controls and in RA. Only in the RA group but not in the control group there was a significant negative correlation of serum iron with CRP (Table 2). The level of serum iron negatively correlated with ESR and DAS 28 in RA (Table 4).

The available information in the scientific literature on the informative value of prohepcidin 
Table 3. Correlations between parameters of inflammation and autoimmune disorders in patients with RA

\begin{tabular}{lccc}
\hline \multirow{2}{*}{ Parameters } & \multicolumn{3}{c}{ RA patients } \\
\cline { 2 - 4 } & $\mathbf{n}$ & $\mathbf{r}$ & $\mathbf{P}$ \\
\hline Prohepcidin / DAS 28 & 114 & 0.266 & 0.004 \\
Prohepcidin / RF & 107 & 0.316 & 0.001 \\
Prohepcidin / ESR & 114 & 0.232 & 0.013 \\
Prohepcidin / CRP & 114 & 0.265 & 0.004 \\
CRP / DAS 28 & 114 & 0.435 & $<0.001$ \\
CRP / RF & 107 & 0.232 & 0.016 \\
CRP / antiCCP & 67 & 0.266 & 0.029 \\
CRP / IL-6 & 59 & 0.553 & $<0.001$ \\
CRP / ESR & 114 & 0.450 & $<0.001$ \\
IL-6 / DAS 28 & 59 & 0.335 & 0.009 \\
IL-6 / ESR & 59 & 0.344 & 0.008 \\
ESR / DAS 28 & 114 & 0.396 & $<0.001$ \\
ESR / Fibrinogen & 108 & 0.436 & $<0.001$ \\
Fibrinogen / RF & 102 & 0.511 & $<0.001$ \\
DAS 28 / RF & 107 & 0.304 & 0.001 \\
DAS 28 / antiCCP & 67 & 0.341 & 0.005 \\
RF / antiCCP & 66 & 0.623 & $<0.001$ \\
\hline
\end{tabular}

Fibrinogen: $4.25 \pm 1.38, \mathrm{n}=108$, ESR: $36(28-58), \mathrm{n}=114$.

for evaluation of the iron status is rather confusing. ${ }^{25-27}$ According to Kim et al. ${ }^{25}$ serum prohepcidin correlates with the activity of the major disease process but not with the anemia condition. On the other hand, in another study ${ }^{27}$, the iron deficiency in RA patients is related with the serum concentration of prohepcidin. The results obtained in our study indicated that the parameter was informative for evaluation of iron deficiency and inflammatory activity in RA: prohepcidin level was significantly higher in RA patients $(\mathrm{P}=0.013)$ (Table 1) and reflected hypoferremia condition in inflammation since it positively correlated with sTfR and with CRP only in RA but not in the controls (Table 2). Prohepcidin is also a sensitive parameter for disorders in RA expressed as its positive correlation with ESR, DAS 28 and RF (Table 3). We didn't find a correlation of prohepcidin with IL-6 which is probably due to the involvement of additional regulatory mechanisms in the conversion of the
Table 4. Correlations between parameters of iron homeostasis, inflammation and autoimmune disorders in patients with RA

\begin{tabular}{lccc}
\hline \multicolumn{1}{c}{ Parameters } & \multicolumn{3}{c}{ RA patients } \\
\cline { 2 - 4 } & $\mathbf{n}$ & $\mathbf{r}$ & $\mathbf{P}$ \\
\hline sTfR / DAS 28 & 114 & 0.308 & 0.001 \\
sTfR / RF & 107 & 0.427 & $<0.001$ \\
sTfR / antiCCP & 67 & 0.400 & 0.001 \\
sTfR / ESR & 114 & 0.252 & 0.007 \\
Serum iron / DAS 28 & 57 & -0.375 & 0.004 \\
Serum iron / ESR & 57 & -0.545 & $<0.001$ \\
TIBC / DAS 28 & 57 & -0.374 & 0.004 \\
TIBC / antiCCP & 24 & -0.424 & 0.039 \\
CRP / Hb & 114 & -0.303 & 0.001 \\
IL-6 / Hb & 59 & -0.343 & 0.008 \\
ESR / Hb & 114 & -0.430 & $<0.001$ \\
ESR / RBC & 106 & -0.302 & 0.002 \\
Hb / Fibrinogen & 108 & -0.401 & $<0.001$ \\
RBC / Fibrinogen & 101 & -0.275 & 0.005 \\
\hline
\end{tabular}

precursor prohepcidin in hepcidin.

IL-6 is involved in autoimmunity by altering the balance between Th17 cells and Treg cells. IL-6 also acts on changing lipid concentrations in blood and on inducing the production of hepcidin which causes IDA. In conclusion, IL-6 is a major player in the pathogenesis of RA, and current evidence indicates that the blockade of IL- 6 is a beneficial therapy for RA patients. ${ }^{3,28}$ Our results confirm the participation of IL-6 both in the hyposideremia (positive correlation with sTfR and negative with serum iron and $\mathrm{Hb}$ ) (Tables 2, 4) and in the inflammatory and autoimmune disorders in RA (positive correlation of IL-6 with ESR, CRP and DAS 28) (Table 3).

According to most of the authors, sTfR is a reliable marker for evaluation of iron deficiency in RA but other authors report that the value of this parameter alone is insufficient. ${ }^{12}$ There is evidence that transferrin receptor modulates the expression of hepcidin. ${ }^{29}$ Some authors propose the determination of serum prohepcidin as a new diagnostic index for ACD in RA. ${ }^{30,31}$

\section{CONCLUSION}

Our study shows that the simultaneous determina- 
tion of two parameters, sTfR and prohepcidin, is most informative for evaluation of the changes in iron homeostasis in RA. The increase of both parameters provides information for tissue iron deficiency (assessed by the level of sTfR), caused by the inflammation when prohepcidin is expressed. This contention is confirmed by the positive correlation of sTfR with prohepcidin only in RA but not in the healthy controls.

\section{ACKNOWLEDGEMENTS}

This research was supported by an Intrauniversity research project (HO-11/2013) funded by the Medical University of Plovdiv.

\section{REFERENCES}

1. Weiss G. Anemia of chronic disease. N Engl J Med 2005;352(10):1011-23.

2. Weiss G. Iron metabolism in the anemia of chronic disease. Biochim Biophys Acta 2009;1790(7):682-93.

3. Raj DS. Role of interleukin-6 in the anemia of chronic disease. Semin Arthritis Rheum 2009;38(5):382-8.

4. Demirag MD, Haznedaroglu S, Sancak B, et al. Circulating hepcidin in the crossroads of anemia and inflammation associated with rheumatoid arthritis. Intern Med 2009;48(6):421-6.

5. Ganz T. Hepcidin - a regulator of intestinal iron absorption and iron recycling by macrophages. Best Pract Res Clin Haematol 2005;18(2):171-82.

6. Benito-Garcia E, Feskanich D, Hu FB, et al. Protein, iron and meat consumption and risk for rheumatoid arthritis: a prospective cohort study. Arthritis Res Ther 2007;9:R16.

7. Telfer JF, Brock JH. Proinflammatory cytokines increase iron uptake into human monocytes and synovial fibroblasts from patients with rheumatoid arthritis. Med Sci Monit 2004;10(4):91-5.

8. Thomas C, Thomas L. Anemia of chronic disease: pathophysiology and laboratory diagnosis. Lab Hematol 2005;11(1):14-23.

9. Wahle M. Anemia in patients with rheumatoid arthritis. Z Rheumatol 2012;71(10):864-8.

10. R'zik S, Beguin Y. Serum soluble transferrin receptor concentration is an accurate estimate of the mass of tissue receptors. Exp Hematol 2001;29(6):677-85.

11. Feelders RA, Kuiper-Kramer EP, van Eijk HG. Structure, function and clinical significance of transferrin receptors. Clin Chem Lab Med 1999;37(1):1-10.

12. Siebert S, Williams BD, Henley R, et al. Single value of serum transferrin receptor is not diagnostic for the absence of iron stores in anaemic patients with rheumatoid arthritis. Clin Lab Haematol 2003; 25(3):155-60.
13. Hanif E, Ayyub M, Anwar M, et al. Evaluation of serum transferrin receptor concentration in diagnosing and differentiating iron deficiency anaemia from anaemia of chronic disorders. J Pak Med Assoc 2005;55(1):13-6.

14. Moore C Jr, Ormseth M, Fuchs H. Causes and significance of markedly elevated serum ferritin levels in an academic medical center. J Clin Rheumatol 2013;19(6):324-8.

15. Ichida H, Kawaguchi Y, Sugiura T, et al. Clinical manifestations of adult-onset Still's disease presenting with erosive arthritis: Association with low levels of ferritin and interleukin-18. Arthritis Care Res (Hoboken) 2014;66(4):642-6.

16. Bari MA, Sutradhar SR, Sarker CN, et al. Assessment of anaemia in patients with rheumatoid arthritis. Mymensingh Med J 2013;22(2):248-54.

17. Pavai S, Jayaranee S, Sargunan S. Soluble transferrin receptor, ferritin and soluble transferrin receptor - ferritin index in assessment of anaemia in rheumatoid arthritis. Med J Malaysia 2007;62(4):303-7.

18. Ravindran V, Jain S, Mathur DS. The differentiation of anaemia in rheumatoid arthritis: parameters of iron-deficiency in an Indian rheumatoid arthritis population. Rheumatol Int 2008;28(6):507-11.

19. Masson C. Rheumatoid anemia. Joint Bone Spine 2011;78(2):131-7.

20. Calisto Pérez C, León R, León F, et al. Rheumatoid arthritis and anemia: the impact of different anti-inflammatory therapies on hemoglobin levels. An observational study. Bol Asoc Med P R 2012;104(2):34-41.

21. Braga F, Infusino I, Dolci A, et al. Soluble transferrin receptor in complicated anemia. Clin Chim Acta 2014;20(431):143-7.

22. Beguin Y. Soluble transferrin receptor for the evaluation of erythropoiesis and iron status. Clin Chim Acta 2003;329(1-2):9-22.

23. Lv F, Song LJ, Li XF. Combined measurement of multiple acute phase reactants to predict relapse of rheumatoid arthritis. Int J Rheum Dis 2015;18(7):725-30.

24. Önder B, Kurtaran A, Kimyon S, et al. Association of anti-CCP positivity with serum ferritin and DAS28. Rheumatol Int 2009;30(2):223-7.

25. Kim H, Kim K, Yoon S, et al. Serum pro-hepcidin could reflect disease activity in patients with rheumatoid arthritis. J Korean Med Sci 2010;25:348-52.

26. Koca SS, Isik A, Ustundag B, et al. Serum pro-hepcidin levels in rheumatoid arthritis and systemic lupus erythematosus. Inflammation 2008;31(3):146-53.

27. Jayaranee S, Sthaneshwar P, Sokkalingam S. Serum prohepcidin concentrations in rheumatoid arthritis. Pathology 2009;41(2):178-82.

28. Hashizume M, Mihara M. The roles of interleukin-6 
in the pathogenesis of rheumatoid arthritis. Arthritis 2011;2011:765624.

29. Schmidt PJ, Toran PT, Giannett AM, et al. Transferrin receptor modulates Hfe-dependent regulation of hepsidin expression. Cell Metab 2008;7(3):205-14. 30. Pasricha SR. Is it time for hepcidin to join the diagnostic toolkit for iron deficiency? Expert Rev Hematol 2012;5(2):153-5.

31. Lemos Ados R, Ismael LA, Boato CC, et al. Hepcidin as a biochemical parameter for the assessment of iron deficiency anemia. Rev Assoc Med Bras 2010;56(5):596-9.

\title{
Патобиохимические механизмы, обеспечивающие связь гомеостаза железа с параметрами воспалительной активности и аутоиммунными заболеваниями при наличии ревматоидного артрита
}

\author{
Катя И. Стефанова ${ }^{1}$, Гинка Т. Делчева ${ }^{1}$, Ана И. Манева ${ }^{1}$, Анастас 3. Баталов ${ }^{2}$, Мариэла Г. \\ Генева-Попова ${ }^{2}$, Росица В. Каралилова ${ }^{2}$, Кирилл К. Симитчиев ${ }^{3}$ \\ ${ }^{1}$ Кафедра химии и биохимии, Факультет фармации, Медицинский университет, Пловдив, Болгария \\ 2 Кафедра пропедевтики внутренних болезней, Факультет медицины, Медицинский университет, Пловдив, Болгария \\ ${ }^{3}$ Кафедра аналитической химии и компьютерной химии, Факультет химии, Пловдивский университет им. Паисия Хилен- \\ дарского, Пловдив, Болгария
}

\begin{abstract}
Адрес для корреспонденции: Катя И. Стефанова, Кафедра химии и биохимии, Факультет фармации, Медицинский университет - Пловдив, ул. Васила Априлова № 15A, Пловдив, 4002, Болгария

E-mail:katia_i_k@yahoo.com Тел.: +35932602358
\end{abstract}

Дата получения: 06 октября 2015 г.

Дата приемки: 07 октября 2016 г.

Дата онлайн публикации: 12 октября 2016 г.

Дата публикации: 23 декабря 2016 г.

Ключевые слова: анемия, ревматоидный артрит, sTfR, феритин, прогепсидин, IL-6

Образец цитирования: Stefanova KI, Delcheva GT, Maneva Al, Batalov AZ, Geneva-Popova MG, Karalilova RV, Simitchiev KK. Pathobiochemical mechanisms relating iron homeostasis to parameters of inflammatory activity and autoimmune disorders in rheumatoid arthritis.

Folia Medica 2016;58(4):257-263 doi: 10.1515/folmed-2016-0040
Цель: Установление корелляции между параметрами гомеостаза железа, воспалительной активности и аутоиммунных заболеваний при наличии ревматоидного артрита (РA).

Материалы и методы: В данное исследование были включены 114 пациентов с РА и контрольная группа, состоящая из 42 здоровых человек. Нами были определены параметры гомеостаза железа: железо в сыворотке крови, общая железо-связывающая способность (TIBC), феритин и растворимый рецептор трансферина (sTfR), параметры воспалительной активности: С-реактивный белок (CRP), интерлевкин-6 (IL-6) и прогепсидин, а также параметры аутоиммунных заболеваний: ревматоидный фактор (RF), антитела к циклическому цитруллиновому пептиду (antiCCP) и DAS 28.

Результаты: Уровень sTfR, CRP, IL-6 и прогепсидина является намного выше у пациентов с РА, чем в контрольной группе, а уровень железа в сыворотке крови намного ниже в группе с РА, чем в контрольной группе. В отличие от контрольной группы, в группе с РА установлена значительная положительная корреляция STfR с параметрами воспалительной активности (IL-6, прогепсидин, ESR) и с параметрами аутоиммунных заболеваний (DAS 28, RF, antiCCP). Отрицательная корреляция уровня железа в сыворотке крови со STfR установлена только у пациентов с РА. Прогепсидин находится в положительной корреляции с параметрами воспалительной активности (CRP, ESR) и с параметрами при оценке аутоиммунных заболеваний (DAS 28 и RF) в группе с PA.

Заключение: Результаты нашего исследования показали, что одновременное определение двух параметров, STfR и прогепсидина, является наиболее информативным для оценки изменений в гомеостазе железа у пациентов с РА. Увеличение обоих параметров несет информацию о дефиците железа в тканях (оценка, основанная на уровне STfR), причиной которого является воспаление в случаях экспрессии прогепсидина. 